\title{
Dry matter and nutrient partitioning of selected pineapple cultivars grown on mineral and tropical peat soils
}

\begin{abstract}
The pineapple cultivars 'Moris' (Queen cultivar), 'N-36' ('Sarawak' × 'Gandul' hybrid), 'Gandul' (Singapore Spanish cultivars), and 'Josapine' ('Singapore Spanish' $\times$ 'Smooth Cayenne' hybrid) are mostly grown on peat soils in Malaysia, whereas 'Sarawak' ('Smooth Cayenne' cultivar) is more commonly grown on mineral soils. To obtain good yields of fruit of high quality, it is important to understand the differences in nutrient requirements for these cultivars in the different soils in which they are grown. Therefore, the objectives of the study were to determine the biomass and nutrient partitioning of the different pineapple cultivars and to determine the plant variables affecting fruit yield and quality. Plants of each of the pineapple cultivars were randomly sampled from different locations of the major pineapplegrowing areas in Malaysia. Only plants having A-grade fruit of marketable quality at harvest were selected. The cultivars and respective field sites were as follows: 'Sarawak,' Bukit Tandak farm, Kelantan ( $\left.5^{\circ} 55.274^{\prime} \mathrm{N}, 102^{\circ} 00.608^{\prime} \mathrm{E}\right)$; 'Moris,' 'N-36,' and 'Gandul,' Peninsula Pineapple Plantations, Simpang Renggam, Johor ( $\left.1^{\circ} 49.909^{\prime} \mathrm{N}, 103^{\circ} 14.053^{\prime} \mathrm{E}\right)$; and 'Josapine,' Goh Swee Eng Pineapple Farm, Simpang Renggam, Johor $\left(1^{\circ} 48.441^{\prime} \mathrm{N}, 103^{\circ}\right.$ $11.935^{\prime}$ E). Plants were partitioned into roots, stem, leaves, peduncle, fruit, and crown, and fresh and dry weights were recorded. Total biomasses for the different cultivars were 733.46 $\pm 22.83 \mathrm{~g}$ for 'Gandul,' $842.34 \pm 43.26 \mathrm{~g}$ for 'N-36,' $927.38 \pm 53.10 \mathrm{~g}$ for 'Moris,' $434.77 \pm$ $16.82 \mathrm{~g}$ for 'Josapine,' and $2446.94 \pm 156.00 \mathrm{~g}$ for 'Sarawak.' Leaves accounted for the greatest proportion of dry matter $(48.5 \%)$, followed by fruit $(22.9 \%)$ and stem $(21.6 \%)$, and a smaller proportion (1.2-2.5\%) was roots, peduncle, and crown. The proportions of the drymatter accumulation in leaves and stem for the cultivars were $53.5 \pm 0.7$ and $16.7 \pm 0.9 \%$ for 'Gandul'; $45.1 \pm 0.5$ and $17.7 \pm 0.7 \%$ for 'N-36'; $51.9 \pm 1.6$ and $16.8 \pm 0.6 \%$ for 'Moris'; 56.5 \pm 1.0 and $12.0 \pm 0.9 \%$ for 'Josapine'; and $54.2 \pm 5.1$ and $27.7 \pm 4.4 \%$ for 'Sarawak.' The proportion of the macro-and micronutrients in pineapple parts differed widely between cultivars. Potassium $(\mathrm{K})$ showed the greatest proportion $(7.96 \pm 0.6$ to $29.73 \pm 1.17 \%)$ in leaves and $(4.46 \pm 0.70$ to $9.35 \pm 0.28 \%)$ in fruit followed by nitrogen $(\mathrm{N})$ and phosphorus $(\mathrm{P})$ with lower proportions. Most pineapple cultivars grown showed variation in nutrient-use efficiency (NUE) with respect to the elements measured with values of $<1.0 \mathrm{~g}$ dry matter g-1 nutrient. The NUE values of $>1.0 \mathrm{~g}$ dry matter g-1 nutrient were observed for magnesium $(\mathrm{Mg})$ in 'Gandul' and 'N-36' and for calcium $(\mathrm{Ca})$ and copper $(\mathrm{Cu})$ in 'N-36.' Total nutrient accumulation in the plant components differed approximately according to their cultivar origins ('Smooth Cayenne,' 'Queen,' 'Singapore Spanish'). It is interesting that the results for the 'Singapore Spanish' $\times$ 'Smooth Cayenne' hybrid Josapine were more similar to the 'Singapore Spanish' cultivars than being between the parents. Partitioning of biomass and nutrients in pineapple provides a means to categorize them and makes it possible to use a cultivar-based fertilization program.
\end{abstract}

Keyword: Biomass partitioning, Mineral soil, Nutrient allocation, Pineapple cultivar, Tropical peat 